\title{
Öğretmenlerin Kariyer Tatmini Düzeylerinin Demografik Değişkenlere Göre İncelenmesi
}

\author{
Mustafa KILINÇ* \\ Muhammet TORTUMLU** \\ Kıvanç UZUN***
}

\section{$\ddot{O} z$}

$\mathrm{Bu}$ araştırmada, öğretmenlerin kariyer tatminlerinin cinsiyet, yaș, kıdem, gelir durumu, medeni hâl, öğrenim durumu ve branş değişkenleri açısından incelenmesi amaçlanmıştır. Bu amaç doğrultusunda çalışmada, nedensel karşılaştırma modeli kullanılmıştır. Araştırma, 2020-2021 eğitim-öğretim yılında Burdur il merkezinde ve ilçelerinde yer alan Millî Eğitim Bakanlığına bağlı resmi ve özel kurumlarda çalışmakta olan 325 öğretmen üzerinde gerçekleştirilmiştir. Çalışma grubunun yaş ortalaması 37.39'dur. Veriler araştırmacıların geliştirdiği kişisel bilgi formu ve Kariyer Tatmini Ölçeği ile toplanmıştır. Verilerin analizinde yüzde, frekans, aritmetik ortalama, standart sapma kullanılmıs olup; farklılıkların tespitine ilişkin analiz için ise ilişkisiz örneklemler t-testi ve tek yönlü varyans analizi kullanılmıştır. Farklılıkların kaynağını test etmek amacıyla Tukey ve Hochberg's GT2 testlerinden yararlanılmıştır. Tüm bu istatistiksel analizlerde SPSS 22.0 programı kullanılmış olup, anlamlılık düzeyi olarak .05 alınmıştır. Araştırmanın sonucunda, öğretmenlerin kariyer tatminlerinin, kıdem, gelir durumu, medeni hâl ve branş değişkenleri açısından anlamlı olarak farklılaştı̆ı̆ ancak cinsiyet, yaş ve öğrenim durumu değişkenlerine göre anlamlı bir farkın olmadığı tespit edilmiştir. Çalışma bulguları ilgili alanyazın ışığında tartışılmıştır.

Anahtar Kelimeler: Kariyer Tatmini, Öğretmenler, Farkl1lık Analizleri, Demografik Değiş̧kenler.

\section{Investigation of Teachers' Career Satisfaction Levels According to Demographic Variables}

\begin{abstract}
The aim of this research is to examine teachers' career satisfaction by gender, age, seniority, income, marital status, educational background and branch variables. For this purpose, the causal comparative method was used in the research. The study was conducted on 325 teachers working in official and private institutions affiliated to the Ministry of National Education located in the city center and districts of Burdur in the academic year of 2020-2021. The mean age of the study group is 37,39. The data of the study were collected by the personal information form developed by the researchers and the Career Satisfaction Scale. In the analysis of the collected data, percentage, frequency, arithmetic mean, standard deviation were used; In addition, independent samples t-test and one-way variance analysis were used to determine the differences and Tukey and Hochberg's GT2 tests were used to test the source of the differences. For all the statistical analyses, SPSS 22.0 program package was used and the significance level was set to be, 05 . As a result of the analyses, the teachers' career satisfaction was found to be varying significantly depending on seniority, income, marital status and branch but not varying significantly depending on gender, age and educational background. Findings of the study were discussed in light of the literature.
\end{abstract}

Keywords: Career Satisfaction, Teachers, Differences Analysis, Demographic Variables.

Geliș/Received: 01.11.2020

Kabul/Accepted: 23.06 .2021

* Bu çalışma, Burdur Mehmet Akif Ersoy Üniversitesi Girişimsel Olmayan Klinik Araştırmalar Etik Kurulu tarafından 07/10/2020 tarihinde 2020/10 nolu toplantıda gerekçe, amaç, yaklaşım ve yöntem açısından incelenmiş olup etik açıdan uygun bulunmuştur (Karar No: GO 2020/257).

\footnotetext{
* Dr. Öğr. Üyesi, Burdur Mehmet Akif Ersoy Üniversitesi, mkilinc@ mehmetakif.edu.tr, (D) 0000-0002-2759-4916

** Öğr. Gör., Burdur Mehmet Akif Ersoy Üniversitesi, mtortumlu@mehmetakif.edu.tr, (D) 0000-0002-7245-1017

**** Öğr. Gör., Burdur Mehmet Akif Ersoy Üniversitesi, kuzun @ mehmetakif.edu.tr, (D) 0000-0002-6816-1789

(Makale türü: Araştırma makalesi)
} 


\section{Giriş}

Öğretim, bilgi ve beceri kazandırma, öğrenmeyi sağlama etkinliğidir (Erdem, 1998). Öğretim etkinliğinin ortaya çıkabilmesi için öğrenmenin gerçekleşmiş olması gereklidir. Dolayısıyla öğrenmenin olmadığı bir yerde öğretmeden bahsetmek de anlamsızdır. Eğitimin en önemli araçlarından biri olan öğretim, eğitim sistemi içerisindeki aktörlerden öğretmenlerin sorumluluğunda bulunmaktadır. Bu kritik sorumluluk, toplumların değişimini ve gelişimini büyük ölçüde etkilemektedir (Sağ, 2003). Küçük yaşlardan itibaren eğitim ve öğretim sürecine başlayan bireyler, yetişkin yaşlarına ulaşana kadar öğretmenleriyle ilişkiler kurmakta ve onları rol model almaktadırlar (Kılınç ve Uzun, 2021). Bu bağlamda öğretmenlerin, bireylerin eğitim hayatlarında önemli bir yeri olduğu söylenebilir. Ancak öğretmenlerin toplum içerisindeki bu öneminin, çeşitli sorumluluklar barındırdığı da bir gerçektir. Öğretmenlerin, özellikle eğitim verdikleri branşlar ile ilgili bilgilerini sürekli güncel tutabilmeleri, hedefleri çerçevesinde mesleki gelişimlerini sağlamaları ve mesleğin gereğince yürütülmesi; okullardaki eğitim kalitesinin yükseltilebilmesi için bir zorunluluktur (The Holmes Group, 1996).

Bilgi çağı ile hızla gelişen teknoloji, tüm meslek gruplarında olduğu gibi öğretmenlik mesleğinde de değişimin baş aktörüdür (Özdemir, 2016). Bu durum, öğretmenlerin mesleki gelişimleri için bilgilerini sürekli güncel tutmaları ve teknolojiyi aktif kullanma becerilerini artırmaları gerekliliğini doğurmuştur. Ancak bunu sağlamaya yönelik yapılan hizmet içi eğitimler de zamanla güncelliğini kaybetmektedir (Gönen ve Kocakaya, 2006). Kendini yetiştiremeyen, geliştiremeyen ve bilgisini güncellemeyen öğretmenlerin, eğitim kalitesini artırması beklenemeyeceği gibi başarısızlık ve tatminsizlik yaşamaları da kaçınılmazdır. Nitekim Rol Teorisine göre çalışanların, görev aldıkları pozisyonlar ile ilgili yeterli bilgi ve birikime sahip olmaması durumunun; memnuniyetsizliği meydana getireceği, kaygı düzeyini yükselteceği ve gerçeklikten uzaklaştırıp performansı düşüreceği belirtilmiştir (Rizzo, House ve Lirtzman, 1970). Özellikle teknolojik gelişmeler, gelişim fırsatları açısından öğretmenlik branşları arasında uçurum oluşturabilir. Fen bilimleri branşındaki öğretmenlerin, diğer branşlardaki öğretmenlere oranla teknolojik gelişimlere daha hızlı ayak uydurabileceklerini söylemek mümkündür. Bu gibi gelişmeler, branş ve benzeri demografik değişkenlere bağlı olarak; öğretmenlerin kariyer gelişimlerinin farklı düzeylerde seyretmesini ve dolayısıyla kariyerlerinden kaynaklı memnuniyetsizliklerinin de farklı oranlarda yaşanmasını kaçınılmaz hale getirebilir. Alanyazın incelendiğinde, çalışanların kariyer tatmini düzeylerini demografik değişkenler kapsamında inceleyen araştırmaların olduğu göze çarpmaktadır (Kendir ve Özkoç, 2018; Tak ve Lim, 2008). Ancak öğretmenlerin kariyer tatmini düzeylerini ve bu düzeylerin hangi demografik değişkenler çerçevesinde farklılaştığını inceleyen bir araştırmaya rastlanılmamıştır. Bu bağlamda, 
öğretmenlerin kariyer tatminlerinin kaynaklarının açıklanmasına yönelik araştırmalara yeterince ağırlık verilmediği ve bu tür çalışmalara daha çok ihtiyaç duyulduğu söylenebilir. Araştırmanın bu bakımdan özgün olduğu ve öğretmenlerin kariyer tatminlerine kuramsal açıdan katkılar sunacağı söylenebilir. $\mathrm{Bu}$ araştırma, öğretmenlerin kariyer tatminlerinin açıklanması ve arttırılması ile ilgili yapılacak çalışmalarda dikkate alınması gereken faktörlerin belirlenmesi bakımından da oldukça önem arz etmektedir.

Öğretmenlerin mesleki gelişimlerini, kariyer hedeflerini, beceri ve niteliklerini artırmalarıyla öğretme faaliyetini gerçekleştirdikleri kitlelere daha çok fayda sağlayacağ söylenebilir (Kılınç ve Uzun, 2021). Bireylerin mesleki başarıları, gelire ilişkin hedefleri, genel mesleki hedefleri, yeni beceriler edinme ve mesleki ilerlemeleri kariyer tatminini oluşturan boyutlardan sayılmaktadır (Vatansever, 2008). Kariyer tatmini, bireylerin mesleğine yönelik olumlu duygularını içermektedir (Shawer ve Alkahtani, 2012). Kariyer tatmini düzeyleri düşük çalışanların, tükenmişlik duygularını daha çok yaşadıkları tespit edilmiştir (Shanafelt, Balch, Bechamps, Russell, Dyrbye, Satele, Collicott, Novotny, Sloan ve Freischlag, 2009). Bu bağlamda öğretmenlerin, kariyer tatminsizliği kaynaklı yaşayabilecekleri tükenmişlik duygusunun; dolaylı yoldan öğretim sistemini de olumsuz yönde etkileyebileceği düşünülebilir.

Çalışanların iş tutumları, çeşitli değişkenlere göre farklılık gösterebilmektedir (Kılınç ve Uzun, 2020). Bu araştırma kapsamında da öğretmenlerin kariyer tatmini tutumlarının; yaş, cinsiyet, kıdem, branş, gelir düzeyi, öğrenim durumu ve medeni hâl değişkenlerine göre farklılık gösterebileceği düşünülmüştür. Nitekim genç yaş grubundaki çalışanların, daha hırslı ve istekli olmalarından dolayı performanslarının daha yüksek olabileceği (Sağdıç ve Demirkaya, 2009); erkeklerin kadınlara göre kariyerlerine daha fazla önem verdikleri (Küçükusta, 2007); eğitim seviyesinin kariyer tatmini sağlamada önemli bir etken olduğu (Demirdelen ve Ulama, 2013); evli kadın çalışanların bekar kadın çalışanlara göre daha fazla kariyer tatmini yaşadıkları (Punnett, Duffy, Fox, Gregory, Lituchy, Miller, Inés-Monserrat, Olivas-Luján ve Santos, 2007); çalışanların çalıştıkları kurum içerisindeki konumlarına göre kariyer tatmin seviyelerinin değişiklik gösterebildiği (Uzunbacak, 2004) gibi tespitler, iş tutumlarına birçok değişkenin etki edebileceğini kanıtlar niteliktedir. Bu bakımdan öğretmenlerin kariyer tatmini düzeylerinin tespit edilmesi ve çeşitli değişkenlerle olan etkileşiminin saptanması; öğretmenlerin bilgi ve birikimlerini sürekli güncel tutmalarına, kariyerlerine dönük olumlu algıları artırabilecek uygulamaların devreye sokulmasına katkıda bulunabilir. Bu bağlamda siyasi otoriteler tarafından ücretlerin yeniden yapılandırılmasının, yeni kariyer aşama ve fırsatlarının oluşturulmasının yolu açabilir. 


\section{Kuramsal Çerçeve}

\section{Kariyer Tatmini}

Son yıllarda örgütlerin, personellerine kariyer planlama olanakları sağlayarak kurumsallaşmaya dönük adımlar attıkları görülmektedir. Bu doğrultuda bireyler ilgi, beceri ve istekleri doğrultusunda; kendilerini tatmin edebileceğini düşündükleri işlere yönelmeye başlamışlardır. Tam da bu noktada kariyer tatmini kavramı ön plana çıkmaktadır. Kariyer tatmini kavramı ilk olarak Kariyer Seçimi Teorisine dayandırılarak Holland ve Super tarafından alanyazına kazandırılmıştır. Holland kariyer tatminini, çalışanların yetenek, inanç, değer, tecrübe ve başarılarından kaynaklandığını ileri sürerken; Super ise kariyer tatmininin, örgütte meydana gelen değişikliklerden de etkilenebildiğini ifade etmiştir (Gürkan ve Koçoğlu, 2014). Kariyer tatmini, çalışanların hedefledikleri kariyere ulaşma derecesinden algıladıkları memnuniyet olarak tanımlanmış ve mesleğe karşı olumlu duyguları içerdiği ifade edilmiştir (Shawer ve Alkahtani, 2012). Başka bir tanımda ise kariyer tatmini, bireyin mevcut yaşadığı kariyer başarısı ile gelecekte hedeflediği kariyer gelişimlerine dönük beklentileri olarak tanımlanmaktadır (Nauta, Vianen, Heijden, Dam ve Willemsen, 2009). Çalışanların, kendi kariyerlerine yönelik ücret, terfi ve gelişim beklentileri gibi içsel ve dışsal tutumları, kariyer tatminlerini oluşturmaktadır (Koçoğlu, 2012). Kariyer tatmininin mesleki başarılar, genel mesleki hedefler, gelire ilişkin hedefler, meslekteki ilerlemeler ve yeni beceriler edinme olmak üzere beş temel bileşeni olduğu ifade edilmiştir (Greenhaus, Parasuraman ve Wormley, 1990). Çalışanların belirledikleri hedeflere ulaşma sürecinde duydukları memnuniyet, kariyer tatmininin en temel noktalarındandır (Yüksel, 2005). Nitekim çalışanlar belirledikleri hedeflere ulaştıklarında kariyer tatmini düzeyleri artarken; mevcut gerçekleştirdikleri işler, amaç ve hedeflerine uygun değilse kariyer tatmin seviyeleri azalmaktadır (Hsu, Chen, Jiang ve Klein, 2003). Buna ek olarak çalışanların kariyer tatmin düzeylerinin düşük olması, kariyer bağlılığını ve iş hayatındaki başarıyı olumsuz etkileyebilmektedir (Demirdelen, 2013). Ayrıca kariyer tatmini seviyesinin düşük olmasının, çalışanların motivasyonunu ve performansını azalttı̆̆ı; ancak devamsızlığı ve iş gücü devir hızını artırdığı belirlenmiştir (Cascio, 1995). Bunun yanında kariyer tatmini yüksek olan bireylerin daha mutlu ve motive oldukları, daha yüksek performans gösterdikleri ifade edilmiştir (Peluchette, 1993). Bu tespit ve bulgulardan hareketle kariyer tatmininin, bireylerin çalışma hayatlarındaki performans, motivasyon ve iyi oluşlarına etki eden önemli bir değişken olduğu anlaşılmaktadır. Örgütler açısından bakıldığında ise kariyer tatmininin, iş gücü devir oranına ve devamsızlığa olan etkisiyle kritik bir rol oynadığı söylenebilir. Tüm örgütler için önemli bir konuma sahip olduğu bilinen kariyer tatmini tutumunun; çalışanların yaş, cinsiyet, kıdem, gelir düzeyi, medeni hâl ve 
öğrenim durumu gibi çeşitli değişkenlerine göre farklılaşabileceği düşünülmektedir. Nitekim birçok araştırma, çeşitli meslek gruplarının kariyer tatmini düzeylerini incelerken bu ilişkileri konu edinmiştir (Judge, Cable, Boudreau ve Bretz, 1995; Seibert ve Kraimer, 2001).

\section{Yaş ile Kariyer Tatmini İlişskisi}

Yaş, bireylerin çalışma hayatlarındaki tutumlarını ve beklentilerini etkilemektedir (Çolakoğlu, Ayyıldız ve Cengiz, 2009). Bu bakımdan çalışanların sahip oldukları yaşın, iş tutumlarından biri olarak kabul edilen kariyer tatmini üzerinde de etkisinin olabileceği düşünülmektedir. Alanyazındaki araştırmalar, bireylerin yaşları ve kariyer tatminleri arasında olumlu ve anlamlı bir ilişkinin olduğunu göstermektedir (Lortie-Lussier ve Rinfret, 2005; Rasdi, Ismail ve Garavan, 2011). Buradan hareketle yaş değişkeninin, çalışanların iş hayatlarındaki beklentilerini ve tutumlarını etkileyen önemli bir faktör olduğu düşünülmektedir (Çolakoğlu ve diğerleri, 2009). Ancak bunun yanında alanyazında birbiriyle çelişen bulgulara da ulaşılmıştır. Örneğin bir araştırmada, genç çalışanların kariyer tatmini düzeylerinin yüksek olduğunun (Yap, Cukier, Holmes ve Hannan, 2010) ortaya konulmasına rağmen, orta yaşlarda kariyer tatmini düzeyinin düştüğü ve yaş ilerledikçe tekrar arttığı ifade edilmektedir (Peluchette, 1993). Bu bulguların tam tersine yaş faktörünün kariyer tatmini ile herhangi bir ilişkisinin olmadığına yönelik araştırmalar da mevcuttur (Ng, Eby, Sorensen ve Feldman, 2005; Punnett ve diğerleri, 2007).

\section{Cinsiyet ile Kariyer Tatmini İliş̧kisi}

Cinsiyet, bireylerin meslek ve kariyer seçimlerinde önemli bir faktördür (Özkişi, 2012). Kariyer tatmini ile cinsiyetin ilişkisini inceleyen araştırmaların çoğu, seçilen örneklemden kaynaklı olarak farklı sonuçlar ortaya koyabilmektedir. Kamu sektöründe çalışanlara yönelik yapılan bir çalışmada, cinsiyetin kariyer tatminini etkilediği tespit edilmiştir (Rasdi ve diğerleri, 2011). Finans alanında hizmet veren bir işletmedeki çalışanlar üzerinde yapılan başka bir araştırmada ise kadınların erkeklerden daha yüksek seviyede kariyer tatminine sahip olduğu anlaşılmıştır (Yap ve diğerleri, 2010). Bir başka çalışmada da cinsiyet ile kariyer tatmini arasında herhangi bir ilişki bulunamamıştır (Ng ve diğerleri, 2005).

\section{Eğitim Düzeyi ile Kariyer Tatmini İlişkisi}

Çalışanların eğitim düzeylerinin artırılması ve öğrenme faaliyetlerinin sürekli hale getirilmesi kariyer tatminine önemli ölçüde katkı sağlamaktadır (Eby, Butts ve Lockwood, 2003). Nitekim yapılmış olan bir çalışmada, kariyer tatmini ile eğitim seviyesi arasında pozitif ve anlamlı bir ilişki bulunmuştur (Hirschi, Nagy, Baumeler, Johnston ve Spurk, 2017). Ancak yapılan araştırmaların, özelde örneklem ve genelde ise kültür faktörünün farklılığından kaynaklı olarak; kariyer tatmini ve eğitim düzeyi ilişkisinin her zaman olumlu yönde olmadığg anlaşılmıştır. 
Ayrıca kariyer tatmini ile eğitim seviyesi arasındaki ilişkiyi araştıran bazı çalışmalarda, bu iki değişken arasında herhangi bir ilişki tespit edilememiştir (Emmerik, Euwema, Geschiere ve Schouten, 2006; Rasdi ve diğerleri, 2011).

\section{Medeni Durum ile Kariyer Tatmini İlişkisi}

Evlilik, bireyin genel hayatını büyük ölçüde etkileyen bir değişim olduğu gibi; benzer şekilde iş yaşamını da doğrudan etkilemektedir. Toplumsal değerler, kültür ve çalışılan kurum gibi değişkenler; bireylerin medeni durumlarının, iş tutumları ile ilişkisinde belirleyiciyi rol oynamaktadır. Alanyazında, bireylerin işlerindeki rollerinden ziyade aile rollerinin ağır basması sonucunda yaşanan çatışma ile kariyer tatmininin olumsuz etkileneceği ifade edilmiştir (Martins, Eddleston ve Veiga, 2002). Öte yandan bazı araştırmalarda ise evliliğin kariyer tatminini olumlu yönde etkilediği saptanmıştır ( $\mathrm{Ng}$ ve diğerleri, 2005; Rasdi ve diğerleri, 2011). Kadın çalışanlara yönelik yapılan bir başka çalışmada ise evli kadınların eşlerinden aldıkları destekten dolayı kariyer tatmin düzeylerinin daha yüksek olduğu belirlenmiştir (Punnett ve diğerleri, 2007).

\section{Kıdem ile Kariyer Tatmini İliş̧kisi}

İş yaşamında edinilen tecrübenin, bireylerin kariyer tatmini seviyelerine etki ettiği düşünülmektedir. Alanyazında, özellikle kurumda çalış1lan sürenin kariyer bağlılığ 1 ve kariyer tatmini duygusuyla ilişkili olduğu ifade edilmiştir (Knight, Crutsinger ve Kim, 2006). Bu bağlamda tatmin duygusu ile tecrübenin olumlu bir ilişkisinin olduğu ileri sürülmüştür (Sevimli ve İşcan, 2005). Ayrıca yapılmış olan çalışmalarda, bir örgütte uzun süre çalışan bireylerin; işe bağlılıklarının daha fazla artacağı, işlerinden daha fazla doyum alacakları ve mutlu olacakları bulgularına ulaşılmıştır (Demirel ve Özçınar, 2009).

\section{Gelir ile Kariyer Tatmini İlişkisi}

Kariyer tatmini, çalışanların mevcut işlerine, gelirlerine ve ilerleme imkânlarına yönelik tutumlarını ve bunlardan aldıkları doyumu ifade etmektedir (Emmerik ve diğerleri, 2006). Nitekim gelire ilişkin hedefler, kariyer tatmininin bileşenlerinden biri olarak sayılmaktadır (Greenhaus ve diğerleri, 1990). Bireylerin meslek hayatlarındaki kariyer tatmini seviyeleri; cinsiyet, yaş, gelir ve çalışma şartları gibi birçok değişkenden etkilenebilmektedir (Kendir ve Özkoç, 2018; Tak ve Lim, 2008). Elde edilen gelir ve ücret beklentisi; çalışanların iyi oluş ve tatmin düzeylerinin, başarı duygularının, hedeflere ulaşmalarının ve kariyer başarısının göstergelerinden sayılmaktadır (Wang, Horng, Cheng ve Killman, 2011). Bu bakımdan çalışanların sahip oldukları yüksek gelirin, mutlaka kariyer başarılarına etki edeceği ifade 
edilerek; iş tatmini ve kariyer tatmini göstergelerinin önemli olduğu vurgulanmıştır (Liu ve Liu, 2008).

Yukarıda ifade edilen kuram ve bulgular ışığında bu araştırmanın amacı; öğretmenlerin kariyer tatmini düzeylerinin; cinsiyet, yaş, kıdem, gelir düzeyi, medeni hâl, öğrenim durumu ve branş değişkenleri açısından anlamlı olarak farklılaşıp farklılaşmadığının tespit edilmesidir. Amaca yönelik olarak oluşturulan araştırma soruları aşağıda belirtilmiştir.

Öğretmenlerin kariyer tatmini düzeyleri;

a) Cinsiyetlerine,

b) Yaşlarına,

c) Kidemlerine,

d) Gelir düzeylerine,

e) Medeni hâllerine,

f) Öğrenim durumlarına,

g) Branşlarına göre anlamlı farklılık göstermekte midir?

\section{Yöntem}

\section{Araştırma Modeli}

$\mathrm{Bu}$ araştırmada, Burdur il merkezinde ve ilçelerinde yer alan Millî Eğitim Bakanlığına bağlı resmi ve özel kurumlarda çalışmakta olan öğretmenlerin; cinsiyet, yaş, kıdem, gelir durumu, medeni hâl, öğrenim durumu ve branş değişkenleri açısından kariyer tatmini puanları arasında anlamlı bir fark olup olmadığının belirlenmesi için nedensel karşılaştırma araştırması modeli kullanılmıştır. İnsan grupları arasındaki farklılıkların nedenlerini ve sonuçlarını koşullar ve katılımcılar üzerinde herhangi bir müdahale olmaksızın belirlemeyi amaçlayan çalışmalara nedensel karşılaştırma araştırması denir (Büyüköztürk, Kılıç-Çakmak, Akgün, Karadeniz ve Demirel, 2016).

\section{Çalışma Grubu}

Araştırmanın çalışma grubunu, 2020-2021 eğitim ve öğretim y1lında, Burdur il merkezinde ve ilçelerinde bulunan Millî Eğitim Bakanlığına bağlı resmi ve özel kurumlarda çalışmakta olan (anaokulu, ilkokul, ortaokul ve ortaöğretim kurumları) 325 öğretmen oluşturmaktadır. Çalışma grubunda yer alan öğretmenlerin yaş ortalaması 37.39 'dur. Çalışma grubu oluşturulurken, seçkisiz olmayan örnekleme yöntemlerinden uygun örnekleme yöntemi kullanılmıştır. Uygun örnekleme, araştırmacıların ihtiyaç duyduğu büyüklükteki bir gruba ulaşana kadar en ulaşılabilir olan yanıtlayıcılardan başlamak üzere örneklemini oluşturmasıdır (Büyüköztürk ve diğerleri, 2016). Bu bağlamda araştırma evrenindeki 3250 öğretmenden (Burdur İl MEM, 2020) araştırmacıların imkânları ve kısıtlamaları (zaman, para vb.) hesaba katılarak; 
evreni temsil ettiği düşünülen \%10'luk bir örneklem oluşturulmasının yeterli olacağ düşünülmüştür (Özen ve Gül, 2007). Öğretmenler araştırma sürecine dâhil edilirken gönüllülük ilkesine dikkat edilmiştir. Araştırmanın örneklemine ilişkin bilgiler Tablo-1'de verilmiştir.

Tablo 1: Örnekleme Ait Tanımlayıcı Bulgular

\begin{tabular}{|c|c|c|c|}
\hline Faktör & Değişken & $\mathbf{n}$ & $\%$ \\
\hline \multirow{2}{*}{ Cinsiyet } & Kadın & 134 & 41.00 \\
\hline & Erkek & 191 & 59.00 \\
\hline \multirow{4}{*}{ Yaş } & $20-29$ aras1 & 95 & 29.00 \\
\hline & 30-39 aras1 & 100 & 31.00 \\
\hline & $40-49$ aras 1 & 69 & 21.00 \\
\hline & 50 ve üstü & 61 & 19.00 \\
\hline \multirow{3}{*}{ Kidem } & $1-10$ aras1 & 171 & 53.00 \\
\hline & $11-20$ aras1 & 82 & 25.00 \\
\hline & 21 ve üstü & 72 & 22.00 \\
\hline \multirow{4}{*}{ Gelir Düzeyi } & 2999 TL ve altı & 60 & 18.50 \\
\hline & 3000 - 4999 TL aras1 & 113 & 35.00 \\
\hline & 5000 - 6999 TL aras1 & 89 & 27.00 \\
\hline & 7000 TL ve üstü & 63 & 19.50 \\
\hline \multirow{2}{*}{ Medeni Hâl } & Bekâr & 125 & 38.00 \\
\hline & Evli & 200 & 62.00 \\
\hline \multirow{2}{*}{ Öğrenim Durumu } & Lisans & 224 & 69.00 \\
\hline & Lisansüstü & 101 & 31.00 \\
\hline \multirow{7}{*}{ Branş } & Din Bilimleri & 49 & 15.50 \\
\hline & Fen Bilimleri & 47 & 14.00 \\
\hline & Kültür, Sanat ve Spor & 40 & 11.00 \\
\hline & Temel Ĕ̆itim Bilimleri & 53 & 18.00 \\
\hline & Sosyal Bilimler & 51 & 16.50 \\
\hline & Teknik Bilimler & 44 & 13.00 \\
\hline & Yabancı Diller & 41 & 12.00 \\
\hline Toplam Öğretmen Sayısı & & 325 & 100.00 \\
\hline
\end{tabular}

Tablo-1 incelendiğinde araştırmaya katılanların \%41.00'inin (n=134) kadın, \%59.00'unun (n=191) ise erkek öğretmenlerden oluştuğu görülmektedir. Katılımcıların \%29.00’u (n=95) 20-29 yaş, \%31.00'i (n=100) 30-39 yaş, \%21.00'i (n=69) 40-49 yaş ve \%19.00'u (n=61) ise 50 ve üstü yaş aralığında yer almaktadır. Araştırmaya katılanların \%53.00’ü (n=171) 1-10 yıl, \%25.00'i (n=82) 11-20 yıl ve \%22.00'si (n=72) 21 ve üstü y1l k1deme sahiptir. Kat1lımc1ların \%18.50'si (n=60) 2999 TL ve altında, \%35.00'i (n=113) 3000 ila 4999 TL arasında, \%27.00'si (n=89) 5000 ila 6999 TL arasında ve \%19.50'si (n=63) 7000 TL ve üstünde gelir kazanmaktadır. Araştırmaya katılanların \%38.00’i (n=125) bekâr iken \%62.00’si (n=200) ise evlidir. 
Katılımcıların \%69.00’u (n=224) lisans, \%31.00'i (n=101) ise lisansüstü mezunudur. Araştırmaya katılan öğretmenlerin \%15.50'si (n=49) din bilimleri, \%14.00’ü $(n=47)$ fen bilimleri, \%11.00’i $(n=40)$ kültür, sanat ve spor bilimleri, \%18.00'i $(n=53)$ temel eğitim bilimleri, \%16.50’si $(n=51)$ sosyal bilimler, \%13.00'ü $(n=44)$ teknik bilimler ve \%12.00'si $(n=41)$ ise yabanc1 diller branşlarında yer almaktadır.

\section{Veri Toplama Araçları}

Araştırmada veri toplama araçları olarak öğretmenlere ilişkin demografik bilgilerin elde edildiği kişisel bilgi formu ve Kariyer Tatmini Ölçeği kullanılmıştır. Kariyer Tatmini Ölçeğinin, bu araştırma kapsamında kullanılabilmesi için fikri mülkiyet hakkı sahiplerinden e-posta yolu ile izin alınmıştır. Alınmış olan bu izin, araştırma sürecine başlanmadan önce Etik Kurul Onayına başvurulurken, başvuru dosyasına dâhil edilmiştir.

\section{Kişisel Bilgi Formu}

Araştırmaya katılan öğretmenlerin, demografik özelliklerine ilişkin veri toplamak amacı ile kişisel bilgi formu oluşturulmuştur. Bu formda öğretmenlere dair kişisel bilgiler (cinsiyet, yaş, kıdem, gelir durumu, medeni hâl, öğrenim durumu ve branş) bulunmaktadır.

\section{Kariyer Tatmini Ölçeği (KTÖ)}

KTÖ, Greenhaus ve diğerleri (1990) tarafindan geliştirilmiştir. Ölçeğin Türk kültürüne uyarlaması Çamur (2019) tarafından yapılmıştır. Ölçek toplam 5 madde ve 5'li Likert tipindedir. Ölçekten alınan puanın yükselmesi, bireyin sahip olduğu kariyer tatmini düzeyinin arttığına işaret etmektedir. Ölçeğin tek boyutu bulunmaktadır. KTÖ’nün genel iç tutarlık katsayısı .89'dur Ölçekte kariyer tatmini, beş farklı durum üzerinden ele alınmıştır. Bunlar: kişinin kariyer başarısına ulaşma, genel kariyer hedefleri, gelir hedefleri, terfi hedefleri ve yeni yetenekler geliştirmeye yönelik hedeflere ulaşma düzeyidir (Çamur, 2019).

KTÖ’nün bu çalışma kapsamında kullanılabilmesi için öncelikle geçerlik ve güvenirlik çalışmaları yapılmıştır. Ölçeğin yapı geçerliğine kanıt sağlamak amacıyla doğrulayıcı faktör analizi yapılmış ve ölçeğin model-veri uyumunun kabul edilebilir düzeyde sağlandığ1 görülmüştür $\left(\mathrm{X}^{2}=5.322, \mathrm{sd}=5, \mathrm{p}=.000, \mathrm{X}^{2} / \mathrm{sd}=1.064, \mathrm{CFI}=.93, \mathrm{NNFI}=.92, \mathrm{RMSEA}=.061\right.$, $\mathrm{SRMR}=.052$ ). Ölçekten elde edilen puanların güvenirliğini belirlemek için ise Cronbahc's alfa iç tutarlık katsayısı hesaplanmıştır. Ölçeğin genel iç tutarlık katsayısı .88 olarak bulunmuştur. Bu değerler göz önüne alındığında ölçeğin arzu edilen referans değerlerini karş1ladığı ve araştırmada kullanılabilecek düzeyde geçerli (Kline, 2014) ve güvenilir (Büyüköztürk, 2014) olduğu söylenebilir.

\section{Verilerin Toplanması}

Araştırmacılar tarafından çalışmaya başlanabilmesi için öncelikle Burdur Mehmet Akif Ersoy Üniversitesi Girişimsel Olmayan Klinik Araştırmalar Etik Kurulu Başkanlığından, çalışmanın etik ilkelere uygun olduğuna dair onay alınmıştır. Sonrasında çalışmanın Burdur il 
merkezinde ve ilçelerinde yer alan Millî Eğitim Bakanlığına bağlı resmi ve özel kurumlarda sağlıklı bir şekilde yürütülebilmesi için Etik Kurul Onayı sunularak gerekli olan tüm resmi izinler alınmıştır. Resmi izinlerin alınmasından sonra veri toplama sürecine başlanmıştır. Ölçek uygulamaları araştırmacılar tarafindan yüz yüze yapılmıştır. Okullardaki her bir öğretmen ile birebir görüşülmüş, araştırmanın içeriği ve veri toplama araçlarıyla ilgili gerekli açıklamalar yapılmıştır. Öğretmenlerden gönüllü olarak araştırmaya katılmaya istekli olanlardan, imzalı olarak bilgilendirilmiş onam formları alınmıştır. Daha sonra öğretmenler tarafından ölçeklerin kurallara uygun bir şekilde doldurulması sağlanmıştır. Yapılan bu uygulama, her öğretmen için ortalama üç dakika kadar sürmüştür. Öğretmenler tarafından tamamlanan ölçekler incelenmiş ve tüm veri toplama araçlarının eksiksiz olarak doldurulduğu anlaşılmıştır.

\section{Verilerin Analizi}

Veri analizinin ilk aşamasında veri setinde kayıp veri olup olmadığı incelenmiş ancak herhangi bir kayıp veriye rastlanmamıştır. Daha sonra parametrik test varsayımlarının karşılanıp karşılanmadığının kontrol edilmesi için veri seti uç değerler bakımından incelenmiştir. Verilerin tek değişkenli normal dağılımına uyup uymadığının belirlenmesi için z testi yapılmıştır. Örneklem büyüklüğünün 100 'den fazla olmasından dolayı -4.00 ile +4.00 arası z puanı referans değeri olarak alınmıştır (Mertler ve Vannatta, 2016). Yapılan uç değer incelemesinde standartlaştırılmış $\mathrm{z}$ puanı, -4.00 ile +4.00 aralığının dışında kalan herhangi bir veriye rastlanılmamıştır.

Veriler analiz işlemleri için hazır hale getirildikten sonra; öncelikle, Kariyer Tatmini Ölçeğinin çalışma kapsamında kullanılabilmesi için mevcut çalışmanın verileri kullanılarak yapı geçerliği ve iç tutarlık güvenirlik katsayısı test edilmiştir. Yapı geçerliğinin test edilmesi için LISREL 8.7 programı kullanılarak doğrulayıcı faktör analizi uygulanmış; iç güvenirlik katsayısının belirlenmesi için ise SPSS 22.0 programı kullanılarak ölçeğin Cronbahc's alfa iç tutarlık katsayısı hesaplanmıştır. Elde edilen değerler, ölçeğin araştırma kapsamında kullanılabilecek düzeyde geçerli ve güvenilir olduğunu göstermektedir. Bu değerler, makalenin veri toplama araçları ile ilgili kısmında ayrıntılı sunulmaktadır.

$\mathrm{Bu}$ araştırma kapsamında öğretmenlerin kariyer tatminlerinin, demografik değişkenlere göre istatistiksel olarak anlamlı bir farklılık gösterip göstermediğini belirlemek amacıyla ilişkisiz örneklemler t-testi ile tek yönlü varyans analizi (ANOVA) yapılmıştır. Varyans analizleri yapılmadan önce veri setinin varyansların homojenliği varsayımını sağlayıp sağlamadığ 1 Levene testi yapılarak kontrol edilmiştir. Levene testi sonucunun istatistiksel olarak anlamlı olmadığı (p>.05) dolayısıyla varyansların homojenliği varsayımının sağlandığı görülmüştür. Ayrıca veri setindeki değişkenlerin normal dağılım varsayımını sağlayıp sağlamadığı da kontrol edilmiştir. 
Her bir değişken için hesaplanan çarpıklık ve basıklık katsayılarının -1.00 ile +1.00 aralığında kalmasından dolayı verilerin normal dağılımdan aşırı sapma göstermediği (Çokluk, Şekercioğlu ve Büyüköztürk, 2014) ve normal dağılım varsayımının sağlandığı görülmüştür. Veri setinin gerekli ön koşulları sağladığı tespit edildikten sonra varyans analizleri yapılmıştır. Farklılıkların kaynağının test edilebilmesi için, öğretmenlerin demografik kategorilerdeki dağılımları göz önüne alınarak; Tukey veya Hochberg's GT2 testlerinden uygun olanı tercih edilmiştir (Field, 2005). Yapılmış olan tüm istatistiksel analizlerde SPSS 22.0 programı kullanılmış ve anlamlılık düzeyi olarak .05 kabul edilmiştir.

\section{Etik Kurul Onay Bilgileri}

$\mathrm{Bu}$ çalışma, Burdur Mehmet Akif Ersoy Üniversitesi Girişimsel Olmayan Klinik Araştırmalar Etik Kurulu tarafindan 07/10/2020 tarihinde 2020/10 nolu toplantıda gerekçe, amaç, yaklaşım ve yöntem açısından incelenmiş olup etik açıdan uygun bulunmuştur (Karar No: GO 2020/257).

\section{Bulgular}

Öğretmenlerin cinsiyetleri açısından kariyer tatmini puanları arasındaki farkın anlamlı olup olmadığını incelemek için ilişkisiz örneklemler t-testi analizi gerçekleştirilmiş ve sonuçlar Tablo-2'de sunulmuştur.

Tablo 2: Öğretmenlerin Cinsiyet Açısından Kariyer Tatmini Puanlarının İncelenmesine Yönelik İlişkisiz Örneklemler T-Testi Sonuçları

\begin{tabular}{llllllll}
\hline Değişken & Cinsiyet & $\mathbf{n}$ & $\overline{\mathbf{x}}$ & $\mathbf{S}$ & $\mathbf{s d}$ & $\mathbf{t}$ & $\mathbf{p}$ \\
\hline \multirow{2}{*}{ Kariyer Tatmini } & Kadın & 134 & 15.06 & 4.92 & & & \\
& Erkek & 191 & 15.15 & 4.37 & 323 & -.141 & .888 \\
\hline
\end{tabular}

Tablo-2'de görüldüğü gibi öğretmenlerin kariyer tatmini puanları, cinsiyete göre istatistiksel olarak anlamlı farklılık göstermemektedir $\left(\mathrm{t}_{(323)}=-.141, \mathrm{p}>.05\right)$. Bu bulgu, kadın $(\overline{\mathrm{x}}=15.06)$ ve erkek $(\overline{\mathrm{x}}=15.15)$ öğretmenlerin birbirlerine çok yakın düzeyde kariyer tatmini puanlarına sahip olduklarını göstermektedir.

Öğretmenlerin yaşlarına göre kariyer tatmini puanları arasında anlamlı bir farkın olup olmadığını saptamaya yönelik tek yönlü varyans analizi yapılmış, sonuçlar Tablo-3’te gösterilmiştir.

Tablo 3: Öğretmenlerin Yaşlarına Göre Kariyer Tatmini Puanlarının İncelenmesine Yönelik Tek Yönlü Varyans Analizi Sonuçları

\begin{tabular}{llllllll}
\hline Değişken & Yaş & $\mathbf{n}$ & $\overline{\mathbf{x}}$ & $\mathbf{S}$ & $\mathbf{F}$ & $\mathbf{p}$ & $\begin{array}{l}\text { Anlamlı } \\
\text { Fark }\end{array}$ \\
\hline \multirow{3}{*}{ Kariyer Tatmini } & 20-29 arası (A) & 95 & 15.23 & 4.51 & & & \\
& 30-39 arası (B) & 100 & 14.77 & 4.29 & 1.036 & .378 & - \\
& 40-49 aras1 (C) & 69 & 15.02 & 4.80 & & & \\
\hline
\end{tabular}


50 ve üstü (D) $\quad 61 \quad 17.15 \quad 5.85$

Tablo-3'de görüldüğü gibi öğretmenlerin kariyer tatmini puanları, yaş düzeylerine göre istatistiksel olarak anlamlı bir farkl11ı göstermemektedir $\left(\mathrm{F}_{(3-321)}=1.036, \mathrm{p}>.05\right)$.

Öğretmenlerin kıdemlerine göre kariyer tatmini puanları arasındaki farkın anlamlı olup olmadığını saptamaya yönelik tek yönlü varyans analizi yapılmış, sonuçlar Tablo-4’te sunulmuştur.

Tablo 4: Öğretmenlerin Kıdemlerine Göre Kariyer Tatmini Puanlarının İncelenmesine Yönelik Tek Yönlü Varyans Analizi Sonuçları

\begin{tabular}{llllllll}
\hline Değişken & Kıdem & $\mathbf{n}$ & $\overline{\mathbf{x}}$ & $\mathbf{S}$ & $\mathbf{F}$ & $\mathbf{p}$ & $\begin{array}{l}\text { Anlamlı } \\
\text { Fark }\end{array}$ \\
\hline \multirow{3}{*}{ Kariyer Tatmini } & 1-10 arası (A) & 171 & 14.83 & 4.51 & & & \\
& 11-20 arası (B) & 82 & 14.30 & 4.01 & $7.431^{* *}$ & .001 & $\begin{array}{l}\text { A-C } \\
\text { B-C }\end{array}$ \\
& 21 ve üstü (C) & 72 & 18.43 & 4.68 & & & \\
\hline
\end{tabular}

**p<.01 Tablo-4'de görüldüğü üzere k1demlerine göre öğretmenlerin kariyer tatmini puanları arasında istatistiksel olarak anlamlı bir fark bulunmaktadır $\left(\mathrm{F}_{(2-322)}=7.431, \mathrm{p}<.01\right)$. Tablo-4 incelendiğinde kıdemleri 21 yıl ve üzerinde olan öğretmenlerin, kıdemleri 1 ila 10 yıl arasında ve kıdemleri 11 ila 20 yıl arasında olan öğretmenlere göre anlamlı düzeyde daha yüksek kariyer tatmini puanlarına sahip oldukları görülmektedir.

Öğretmenlerin gelir düzeylerine göre kariyer tatmini puanları arasında anlamlı bir farkın olup olmadığını saptamaya yönelik tek yönlü varyans analizi yapılmış, sonuçlar Tablo-5'te verilmiştir.

Tablo 5: Öğretmenlerin Gelir Düzeylerine Göre Kariyer Tatmini Puanlarının İncelenmesine Yönelik Tek Yönlü Varyans Analizi Sonuçları

\begin{tabular}{llllllll}
\hline Değişken & Gelir Düzeyi & $\mathbf{n}$ & $\overline{\mathbf{x}}$ & $\mathbf{S}$ & $\mathbf{F}$ & $\mathbf{p}$ & $\begin{array}{l}\text { Anlamlı } \\
\text { Fark }\end{array}$ \\
\hline & 2999 TL ve altı (A) & 60 & 15.27 & 2.82 & & & \\
& 3000 - 4999 TL aras1 (B) 113 & 13.98 & 4.67 & & & \\
Kariyer Tatmini & 5000 - 6999 TL aras1 (C) 89 & 16.51 & 4.45 & & .003 & B-C \\
& 7000 TL ve üstü (D) 63 & 16.00 & 4.43 & & & \\
\hline
\end{tabular}

**p<.01 Tablo-5'te görüldüğü gibi öğretmenlerin kariyer tatmini puanları, gelir düzeylerine göre istatistiksel olarak anlamlı bir şekilde farklılaşmaktadır $\left(\mathrm{F}_{(3-321)}=4.704, \mathrm{p}<.01\right)$. Tablo-5'e göre 5000 ila 6999 TL arasında kazanan öğretmenlerin, 3000 ila 4999 TL arasında kazanan öğretmenlere göre anlamlı düzeyde daha yüksek kariyer tatmini puanlarına sahip olduğu söylenebilir.

Öğretmenlerin medeni durumlarına göre kariyer tatmini puanları arasındaki farkın anlamlı olup olmadığını incelemek için ilişkisiz örneklemler t-testi analizi gerçekleştirilmiş ve sonuçlar Tablo-6' da sunulmuştur. 
Tablo 6: Öğretmenlerin Medeni Durumlarına Göre Kariyer Tatmini Puanlarının İncelenmesine Yönelik İlişkisiz Örneklemler T-Testi Sonuçları

\begin{tabular}{llllllll}
\hline Değişken & Medeni Hâl & $\mathbf{n}$ & $\overline{\mathbf{x}}$ & $\mathbf{S}$ & $\mathbf{~ s d}$ & $\mathbf{t}$ & $\mathbf{p}$ \\
\hline \multirow{2}{*}{ Kariyer Tatmini } & Bekâr & 125 & 14.09 & 4.88 & \multirow{2}{*}{323} & $-2.244^{*}$ & .026 \\
& Evli & 200 & 15.60 & 4.35 & & & \\
\hline
\end{tabular}

*p<.05 Tablo-6' da görüldüğü gibi öğretmenlerin kariyer tatmini puanları, medeni durumlarına göre istatistiksel olarak anlamlı bir farklılık göstermektedir $\left(\mathrm{t}_{(323)}=-2.244, \mathrm{p}<.05\right)$. Bu bulgu, evli öğretmenlerin $(\bar{x}=15.60)$, bekâr $(\bar{x}=14.09)$ öğretmenlere göre daha yüksek düzeyde kariyer tatmini puan ortalamasına sahip olduklarını göstermektedir.

Öğretmenlerin öğrenim durumları açısından kariyer tatmini puanları arasındaki farkın anlamlı olup olmadığını incelemek için ilişkisiz örneklemler t-testi analizi gerçekleştirilmiş ve sonuçlar Tablo-7'de gösterilmiştir.

Tablo 7: Öğretmenlerin Öğrenim Durumları Açısından Kariyer Tatmini Puanlarının İncelenmesine Yönelik İlişkisiz Örneklemler T-Testi Sonuçları

\begin{tabular}{llllllll}
\hline Değişken & $\begin{array}{l}\text { Öğrenim } \\
\text { Durumu }\end{array}$ & $\mathbf{n}$ & $\overline{\mathbf{x}}$ & $\mathbf{S}$ & $\mathbf{s d}$ & $\mathbf{t}$ & $\mathbf{p}$ \\
\hline \multirow{2}{*}{ Kariyer Tatmini } & Lisans & 224 & 15.12 & 4.46 & 323 & -.028 & .977 \\
& Lisansüstü & 101 & 15.14 & 5.02 & & & \\
\hline
\end{tabular}

Tablo-7'de görüldüğü gibi öğretmenlerin kariyer tatmini puanları, öğrenim durumlarına göre istatistiksel olarak anlamlı farkl11ık göstermemektedir $\left(\mathrm{t}_{(323)}=-.028, \mathrm{p}>.05\right)$. Bu bulgu, lisans $(\overline{\mathrm{x}}=15.12)$ ve lisansüstü $(\overline{\mathrm{x}}=15.14)$ öğrenim düzeyine sahip olan öğretmenlerin birbirlerine çok yakın düzeyde kariyer tatmini puanlarına sahip olduklarını göstermektedir.

Öğretmenlerin branşlarına göre kariyer tatmini puanları arasında anlamlı bir farkın olup olmadığını saptamaya yönelik tek yönlü varyans analizi yapılmış, sonuçlar Tablo-8'de gösterilmiştir.

Tablo 8: Öğretmenlerin Branşlarına Göre Kariyer Tatmini Puanlarının İncelenmesine Yönelik Tek Yönlü Varyans Analizi Sonuçları

\begin{tabular}{llllllll}
\hline Değişken & Branş & $\mathbf{n}$ & $\overline{\mathbf{x}}$ & $\mathbf{S}$ & $\mathbf{F}$ & $\mathbf{p}$ & $\begin{array}{l}\text { Anlamlı } \\
\text { Fark }\end{array}$ \\
\hline & Din Bilimleri (A) & 49 & 14.34 & 5.24 & & & \\
& Fen Bilimleri (B) & 47 & 17.00 & 4.04 & & & \\
Kariyer & Kültür, Sanat ve Spor (C) & 40 & 11.41 & 4.01 & & & \\
Tatmini & Temel Eğitim Bilimleri (D) & 53 & 16.02 & 4.13 & $3.392^{* *}$ & .003 & B-C \\
& Sosyal Bilimler (E) & 51 & 15.08 & 4.49 & & & \\
& Teknik Bilimler (F) & 44 & 16.00 & 4.34 & & & \\
& Yabancı Diller (G) & 41 & 13.00 & 3.90 & & & \\
\hline
\end{tabular}

**p<.01 
Tablo-8'de görüldüğü üzere branşlarına göre öğretmenlerin kariyer tatmini puanları arasında istatistiksel olarak anlamlı bir fark bulunmaktadır $\left(\mathrm{F}_{(6-318)}=3.392, \mathrm{p}<.01\right)$. Tablo-8 incelendiğinde Fen Bilimleri ve Temel Eğitim Bilimleri öğretmenlerinin, Kültür, Sanat ve Spor Dallarındaki öğretmenlere göre anlamlı derecede daha yüksek kariyer tatmini yaşadıkları söylenebilir.

\section{Sonuç ve Tartışma}

Çalışanların mevcut kariyer başarısı ile gelecekte hedefledikleri kariyer gelişimlerine dönük beklentileri olarak tanımlanan kariyer tatmini, bireylerin hedefledikleri kariyere ulaşma derecesinden algıladıkları memnuniyettir. Bu memnuniyet derecesinin, bireyin meslek hayatına ve iş davranışlarına etkisi birçok araştırmaya konu olmuştur. Nitekim, kariyer tatmininin çalışanların işten ayrılma niyetini doğrudan etkilediğini (Gerçek, Elmas-Atay ve Dündar, 2015) ve tükenmişlik düzeyleriyle doğrudan ilişkili olduğunu (Shanafelt ve diğerleri, 2009) ortaya koyan çalışmalar mevcuttur. Bu ve buna benzer bulgular, kariyer tatmininin hem birey hem de örgüt açısından önemli bir iş tutumu olduğunu göstermektedir. Bu bulguların yanında, kariyer tatmininin çok yönlü yapısı da göz önüne alındığında; kariyer tatmininin birçok değişken ile ilişkili olabileceği düşünülmektedir. Bu bakış açısı ile yapılmış olan bir araştırmada, çalışanların demografik özelliklerinin kariyer tatmini düzeylerine etkisi ortaya konulmuştur (Demirdelen ve Ulama, 2013). Bu araştırmada ise eğitim ve öğretim sisteminin önemli aktörlerinden biri olan öğretmenlerin, kariyer tatmini düzeylerinin; cinsiyet, yaş, kıdem, gelir düzeyi, medeni hâl, öğrenim durumu ve branş değişkenleri açısından farklılaşıp farklılaşmadı̆̆ı tespit edilmeye çalış1lmıştır.

Araştırma sonucunda elde edilen bulgulardan birincisinde; öğretmenlerin kariyer tatmini düzeylerinin, cinsiyetlerine göre anlamlı bir farklılık oluşturmadığ 1 tespit edilmiş̧ir. Alanyazında çeşitli örneklemler üzerinde yapılan çalışmalar incelendiğinde; bazı araştırmalarda cinsiyet, kariyer tatmini üzerinde anlamlı bir fark oluştururken (Rasdi ve diğerleri, 2011; Yap ve diğerleri, 2010) bazılarında ise herhangi bir anlamlı farklılık göstermemiştir (Peluchette, 1993). Bu araştırmadaki bulgulara göre ise, kadın öğretmenlerin kariyer tatmini düzeyleri $(\overline{\mathrm{x}}=15.06)$ ile erkek öğretmenlerin $(\bar{x}=15.15)$ kariyer tatmini düzeylerinin birbirine çok yakın olması, anlamlı bir farkın olmadığı sonucunu doğrulamaktadır. Bu sonucun ortaya çıkmasının sebebi, çalışma grubunun öğretmenlerden oluşması olabilir. Zira farklı örneklemler üzerinde yapılan birçok araştırmada; cinsiyetin, çalışanların kariyer tatmini düzeylerinde anlamlı farklılıklar oluşturduğu görülmüştür (Rasdi ve diğerleri, 2011; Yap ve diğerleri, 2010). Köklü bir meslek olan öğretmenliğin herhangi bir cinsiyetin mesleği olarak görülmemesi, okullarda kadın ve erkek 
öğretmen sayılarının birbirine çok yakın olması, öğretmenler arasında cinsiyet bağlamında maaş, terfi vb. farklı1ıkların bulunmaması bu sonucun ortaya çıkmasına neden olmuş olabilir.

Araştırma bulgularının ikincisinde, öğretmenlerin kariyer tatmini düzeylerinin yaş gruplarına göre anlamlı bir şekilde farklılaşmadığı tespit edilmiştir. Bu bağlamda öğretmenlerin kariyer tatmini düzeylerinin, içinde bulundukları yaştan etkilenmediği söylenebilir. Alanyazındaki birçok çalışma, araştırmanın bulgularına paralel olarak, çalışanların yaşlarına göre kariyer tatmini düzeylerinin anlamlı bir fark göstermediğini tespit etmiştir ( $\mathrm{Ng}$ ve diğerleri, 2005; Punnett ve diğerleri, 2007). Özellikle öğretmenlerin mesleğe başlangıcından emeklilik süresine kadar daima öğretmen unvanı ile devam etmeleri, kısıtlı kariyer imkânları, yirmi beş yaşındaki bir öğretmen ile elli yaşındaki bir öğretmen arasında ciddi bir maaş ve statü farkının olmaması gibi nedenler; öğretmenlerin bulundukları yaşın kariyer tatminleri ile ilişkisinin olmadığı tespitinin gerekçelerinden biri olabilir. Türkiye'de sayıları bir milyonu aşmış durumda olan öğretmen camiasının terfi imkânlarının darlı̆̆g, dikey ve yatay kariyer basamaklarının kısıtlılı̆̆ı, çok sayıda öğretmenin durağan bir iş hayatı geçirmelerinin nedenlerinden olabilir.

Araştırma bulgularının üçüncüsünde, öğretmenlerin kariyer tatmini düzeylerinin kıdemlerine göre anlamlı olarak farklılaştığı tespit edilmiştir. Elde edilen sonuçlara göre öğretmenler arasında 21 yıl ve üzeri tecrübeye sahip olanların, 1 ila 10 yıl ve 11 ila 20 yıl arasında tecrübeye sahip olanlardan daha fazla kariyerlerinden tatmin oldukları saptanmıştır. Bireylerin, çalıştıkları kurumlara vermiş oldukları emeğin ve çalışma sürelerindeki artışın; kariyer bağl1lıkları, kariyer beklentileri, kariyer tatminleri ile doğrudan ilişkili olduğu ifade edilmiştir (Knight ve diğerleri, 2006). Günümüzde tecrübeli öğretmenlerin çoğunun X kuşağına dâhil olduğu düşünüldüğünde; genç öğretmenlere göre daha tatminkâr ve sabırlı oldukları söylenebilir. Diğer yandan tecrübeli öğretmenlerin birçok öğrenci mezun etmeleri, bu öğrencilerden yıllar sonra olumlu geri bildirimler almaları, ortaya koydukları emeklerinin bir karşıllı̆ı olduğunu görmeleri ve kendilerini mesleki açıdan yeterli ve verimli hissetmelerine neden olmaktadır. Nitekim bu durumun, tespit edilen bulgunun temel gerekçelerinden biri olduğu düşünülmektedir. Ayrıca, bireylerin işe ilk girişlerinden sonra yenilikten ve ilk beklentilerden kaynaklı olarak göreli oluşan kariyer doyumlarının, 2 ila 5 yıl çalışma süresince düştüğü, 6 yıl ve üzerine çıktıktan sonra ise tekrar arttığı ifade edilmektedir (Ronen, 1978). Öğretmenlerin büyük bir kısmının, mesleğe başladıktan birkaç yıl sonra, işlerine dair doyumsuzluk yaşadıklarını ifade ederek lisansüstü eğitim almaya yönelmelerinin, bu durumun bir sonucu olduğu düşünülmektedir.

Araştırma bulgularının dördüncüsünde, öğretmenlerin kariyer tatmini düzeylerinin gelir düzeylerine göre anlamlı bir şekilde farklılık gösterdiği tespit edilmiştir. Özellikle 5000 ila 6999 TL geliri olan öğretmenlerin, 3000 ila 4999 TL geliri olan öğretmenlerden daha fazla kariyerlerinden tatmin oldukları anlaşılmıştır. Bu bağlamda öğretmenlerin gelir düzeylerinin, kariyer tatminlerini etkilediği söylenebilir. Alanyazın incelendiğinde, kariyer tatmininin 
belirleyicilerinden birinin de gelire ilişkin hedefler olduğu görülmektedir (Greenhaus ve diğerleri, 1990). Yüksek düzeyde gelir sahibi olmanın, bireylerin temel ve ikincil ihtiyaçlarını karşılamaları konusunda önemli bir kolaylaştırıcı etken olduğu; buna bağlı olarak yüksek düzeyde gelirin, bireylerin genel yaşam doyumlarına önemli ölçüde katkı sağladığı gibi kariyer tatminlerini de olumlu yönde etkileyeceği düşünülmektedir.

Araştırma bulgularının beşincisinde, öğretmenlerin kariyer tatmini düzeylerinin medeni durumlarına göre anlamlı olarak farklılaştığı tespit edilmiştir. Araştırma sonucunda elde edilen, evli öğretmenlerin kariyer tatmini düzeylerinin $(\overline{\mathrm{x}}=15.60)$ bekâr öğretmenlerin kariyer tatmini düzeylerinden ( $\bar{x}=14.09)$ daha yüksek olduğu bulgusu, anlamlı bir farkın oluştuğu sonucunu doğrulamaktadır. $\mathrm{Bu}$ bağlamda evli öğretmenlerin, bekâr öğretmenlerden daha fazla kariyerlerinden tatmin oldukları söylenebilir. Nitekim, alanyazındaki birçok araştırmanın sonucu da evliliğin kariyer tatminini artırdığını tespit etmiştir (Ng ve diğerleri, 2005; Rasdi ve diğerleri, 2011). Evli olan bireylerin eşlerinden olumlu geri bildirim almaları ve hem özel yaşamlarında hem de kariyerlerinde eşlerinden destek görmeleri (Punnett ve diğerleri, 2007) bu sonucun ortaya çıkmasına neden olmuş olabilir.

Araştırma bulgularından altıncısında, öğretmenlerin kariyer tatmini düzeylerinin öğrenim durumlarına göre anlamlı olarak farklılaşmadığı tespit edilmiştir. Bu bağlamda öğretmenlerin öğrenim durumlarının, kariyer tatmini seviyeleri üzerinde belirleyici olmadığı söylenebilir. Lisans düzeyi mezuniyete sahip öğretmenlerin kariyer tatmini düzeyleri $(\bar{x}=15.12)$ ile lisansüstü mezuniyete sahip öğretmenlerin kariyer tatmini düzeylerinin $(\bar{x}=15.14)$ birbirlerine çok yakın olması bu sonucu doğrular niteliktedir. Alanyazın incelendiğinde, bu araştırmanın sonuçlarına paralel olarak; çalışanların, kariyer tatmini ile öğrenim düzeyleri arasında anlamlı bir farkın tespit edilemediği görülmektedir (Emmerik ve diğerleri, 2006; Rasdi ve diğerleri, 2011). Bu sonuçların, öğrenim düzeyi yüksek çalışanların kariyerlerinden beklentilerinin ve hedeflerinin yüksek olmasına rağmen elde ettikleri kazanımlarının düşük kalmasından kaynaklandığ düşünülmektedir (Gattiker ve Larwood, 1987).

Araştırma bulgularından yedincisinde, öğretmenlerin kariyer tatmini düzeylerinin branşlarına göre anlamlı bir şekilde farklılaştığı tespit edilmiştir. Fen Bilimleri ve Temel Eğitim Bilimleri branşlarında öğretmenlik yapanların, Kültür, Sanat ve Spor Dallarındaki öğretmenlere göre kariyerlerinden daha fazla tatmin oldukları bulgusuna ulaşılmıştır. Teknolojideki hızlı değişim, teknolojiye bağlılığın artışı, sosyal hayatın ve iş hayatının her aşamasında teknolojinin varlı̆̆1; fen bilimlerine olan ilgiyi sürekli artırdığından dolayı bireylerin, eğitim ve gelişime yönelik tercihlerini de etkileyeceği düşünülmektedir. Nitekim alanyazın incelendiğinde, ilk ve ortaokul öğrencilerinin fen konularına yönelik ilgi düzeylerinin yüksek olduğu tespit edilmiştir 
(Güven-Yıldırım ve Köklükaya, 2016). Yine yapılan başka bir çalışmada ilköğretim öğrencilerinin fen dersine yönelik ilgi ve tutumlarının yüksek olduğu görülmüştür (Yaman ve Öner, 2006). En çok sevilen ve ilgiyle dinlenen derslerin tespiti için yapılan bir araştırmada ise fen bilgisi dersi, 12 ders arasından en sevilen 5. ders olarak bulunmuştur (Hendley, Stables ve Stables, 1996). Öğrencilerin bu ilgisi, velilerde de bu alana yönelik olumlu bakış açısı oluşturmaktadır. Velilerin, öğretmenlere yönelik olumlu ve bilgilendirici yaklaşımları; öğretmen performanslarını artıran etkenler arasında gösterilmektedir (Hatipoğlu ve Kavas, 2016). Buradan hareketle fen bilimlerine karşı oluşan ilgi, yönelim ve sevginin; fen bilimleri branşındaki öğretmenlerin kariyer tatmini düzeylerini olumlu anlamda etkilemiş olabileceği düşünülmektedir. Temel Eğitim Bilimleri branşındaki öğretmenler ise küçük yaşlarda bulunan öğrencilere eğitim ve öğretim hizmeti vermektedirler. Gelişim için kritik öneme sahip olan erken yaşlarda, öğrencilerin gelişmeye ve yönlendirilmeye daha yatkın olmaları, öğretmenlerle kurulan güçlü duygusal bağlar; Temel Eğitim Bilimleri branşındaki öğretmenlerin kariyer tatminlerini olumlu anlamda etkilemiş olabilir.

Kültür, sanat ve spor branşlarındaki öğretmenlerin, Temel Eğitim ve Fen Bilimleri öğretmenlerine göre daha düşük kariyer tatmini düzeylerine sahip olmasının birçok nedeni olabilir. Yapılan bir araştırmada öğrencilerin, öğretmenlerin ve velilerin görsel sanatlar dersini önemsemesine rağmen uygulamada karşılı̆̆ını bulamamasının, gerekli fiziksel koşulların yeterince sağlanmamasından kaynaklandığı ifade edilmiştir (Avşar ve Soğancı, 2011; Tarı, 2011). Çakmak ve Türkcan (2019) yaptıkları bir araştırmada görsel sanatlar branşındaki öğretmenlerin, derslerde kendilerini yetersiz gördüklerini ve velilerin, çocuklarından bu derslerle ilgili herhangi bir beklenti içerisinde olmadıklarını tespit etmişlerdir. Nitekim bu durum, görsel sanatlar branşındaki öğretmenlerin kariyer tatminlerini olumsuz yönde etkileyebilir. Zira velilerin yaklaşımları, öğretmenlerin performanslarına etki edebilmektedir (Hatipoğlu ve Kavas, 2016). Ayrıca yapılan başka bir araştırmada, beden eğitimi ve spor branşındaki öğretmenlerin de yeterlilik algılarının orta düzeyde olduğu tespit edilmiştir (Varol ve Türkmen, 2017).

\section{Öneriler}

Araştırmanın ortaya koyduğu bulgulardan yola çıkarak, öğretmenlerin sahip oldukları kariyer tatmini düzeylerinin iyileştirilmesi için gelir seviyelerinin de mümkün olduğunca iyileştirilmesi, mesleki başarılarına ve ilerlemelerine yönelik çeşitli teşvik programlarının geliştirilebilmesi, öğretmenlik alanına yönelik yeni eğitim ve gelişim firsatlarının sunulması önerilmektedir. Ayrıca öğrencilere ve velilerine, kişisel gelişim açısından kültür, sanat ve spor derslerinin önemini vurgulayan seminerler düzenlenebilir ve bu dersleri veren öğretmenlerin önemi vurgulanabilir. Bu araştırmada öğretmenlerin kariyer tatmini düzeylerinin cinsiyet, yaş, kıdem, gelir düzeyi, medeni hâl, öğrenim durumu ve branş değişkenlerine göre farklılaşıp 
farklılaşmadığı incelenmiştir. Bundan sonra yapılacak olan çalışmalarda öğretmenlerin kariyer tatminleri üzerinde etkisi olduğu düşünülen diğer demografik değişkenler (özel okul veya devlet okulunda çalışmak vb.) üzerinde durulabilir. Ayrıca öğretmenlerin kariyer tatminleri konusunda ilişkisel çalışmalar planlanarak, öğretmenlerin kariyer tatminlerini yordayan değişkenlerin (yaşam doyumu, iş memnuniyeti vb.) tespit edilmesi sağlanabilir. Nitel araştırma geleneği kullanılarak, öğretmenler ile yapılacak olan bireysel veya odak grup görüşmeleriyle; öğretmenlerin kariyer tatminleri hakkında farklı bakış açıları ortaya çıkarılabilir ve ulaşılan sonuçlar zenginleştirilebilir. Öte yandan başka meslek gruplarının (akademisyenler, avukatlar vb.) kariyer tatminlerine yönelik çalışmalar da planlanabilir ve çeşitli meslek gruplarının kariyer tatmini düzeyleri karşılaştırılabilir.

\section{Sinırlılıklar}

Her araştırmada olduğu gibi bu araştırmanın da kısıtları mevcuttur. Araştırma, Burdur il merkezinde ve ilçelerinde 2020-2021 eğitim öğretim yılında Millî Eğitim Bakanlığına bağlı resmi ve özel kurumlarda çalışmakta olan 325 öğretmenin; kişisel inançlarını ve mevcut değişkenleri ölçmek için geliştirilmiş kişisel bilgi formu ve kariyer tatmini ölçeği ile toplanan verilerle sınırlandırılmıştır. Dolayısıyla veriler, öğretmenlerin kişisel değerlendirmeleri sonucunda elde edilmiştir. Öğretmenlerin, ölçeklerde yer alan maddelerde işaretleyerek gösterdikleri tepkileri; öz-saygılarını korumak ve anlam arayışlarını zedelememek için gerçek yaşamdaki davranışlarıyla bağdaşmayabilir. Bundan dolayı mevcut değişkenleri içerecek şekilde farklı illerde ve ilçelerde de benzer çalışılmaların planlanması ve sonuçlarının karşılaştırılması önerilmektedir.

Yazar Katkıları: $\mathrm{Bu}$ çalışmanın problem durumunun ortaya konmasına, verilerin toplanmasına ve çalışmanın tüm bölümlerinin gözden geçirilerek revize edilmesine birinci yazar Mustafa KILINÇ; giriş, kuramsal çerçeve, sonuç ve tartışma bölümlerine ikinci yazar Muhammet TORTUMLU ve elde edilen verilerin analizinin yapılarak yöntem, bulgular, öneriler ve sınırlılıklar bölümlerinin yazılmasına ise üçüncü yazar Kıvanç UZUN katkı sağlamıştır.

Çıkar Beyanı: Yazarlar, araştırmanın potansiyel bir çıkar çatışması olarak yorumlanabilecek herhangi bir ticari veya finansal ilişki olmaksızın yürütüldüğünü beyan eder.

Teşekkür: Verilerin toplanma sürecine yardımcı olan Burdur İl Milli Eğitim Müdürlüğü’ne teşekkür ederiz.

\section{Kaynakça}

Avşar, P. ve Soğancı, İ. Ö. (2011). Sınıf öğretmeninin yürüttüğü görsel sanatlar dersine yönelik öğrenci yaklaşımları: KonyalŞeydişehir örneği. İlköğretim Online, 10(1), 348-363.

Burdur İl Milli Eğitim Müdürlüğü (2020, 14 Eylül). Öğretmen sayıları. Erişim adresi: http://burdur.meb.gov.tr/ 
Büyüköztürk, Ş. (2014). Sosyal bilimler için veri analizi el kitabı (19.Basım). Ankara: Pegem Akademi.

Büyüköztürk, Ş., Kılıç-Çakmak, E., Akgün, Ö. E., Karadeniz, Ş. ve Demirel, F. (2016). Bilimsel araştırma yöntemleri (21.Basım). Ankara: Pegem Akademi.

Cascio, W. F. (1995). Managing human resources: Productivity, quality of work life, profits (4.Basim). New York: McGraw-Hill.

Çakmak, N. ve Türkcan, B. (2019). Değişmeyen algılar, değişmeyen sorunlar: Öğrenci-öğretmenveli bağlamında ilkokul görsel sanatlar dersi. Ë̆itimde Nitel Araştırmalar Dergisi, 7(2), 768-791. https://doi.org/10.14689/issn.2148-2624.1.7c.2s.13m

Çamur, Ş. (2019). Tükenmişlik ile işten ayrılma niyeti arasındaki ilişkide kariyer tatmininin aracı etkisi ve bir araştırma (Yayımlanmamış yüksek lisans tezi). Marmara Üniversitesi Sosyal Bilimler Enstitüsü, İstanbul.

Çokluk, Ö., Şekercioğlu, G. ve Büyüköztürk, Ş. (2014). Sosyal bilimler için çok değişkenli istatistik: SPSS ve LISREL uygulamaları (3.Basım). Ankara: Pegem Akademi.

Çolakoğlu, Ü., Ayyıldız, T. ve Cengiz, S. (2009). Çalışanların demografik özelliklerine göre örgütsel bağlılık boyutlarında algılama farklılıkları: Kuşadasındaki beş yıldızlı konaklama işletmeleri örneği. Anatolia: Turizm Araştırmaları Dergisi, 20(1), 77-89.

Demirdelen, D. (2013). Yöneticilerin kariyer tatminine ilişkin görüş ve algılamaları: Antalya'da 5 ylldızlı otel işletmelerinde bir araştırma (Yayımlanmamış yüksek lisans tezi). Sakarya Üniversitesi Sosyal Bilimler Enstitüsü, Sakarya.

Demirdelen, D. ve Ulama, Ş. (2013). Demografik değişkenlerin kariyer tatminine etkileri: Antalya'da 5 yıldızlı otel işletmelerinde bir araştırma. Işsletme Bilimi Dergisi, 1(2), 6589.

Demirel, Y. ve Özçınar, M. F. (2009). Örgütsel vatandaşlık davranışının iş tatmini üzerine etkisi: Farklı sektörlere yönelik bir araştırma. İktisadi ve İdari Bilimler Dergisi, 23(1), 129145.

Eby, L. T., Butts, M. ve Lockwood, A. (2003). Predictors of success in the era of the boundaryless career. Journal of Organizational Behavior, 24(6), 689-708. https://doi.org/10.1002/job.214

Emmerik, H. V., Euwema, M. C., Geschiere, M. ve Schouten, M. F. A. G. (2006). Networking your way through the organization, gender differences in the relationship between network participation and career satisfaction. Women in Management Review, 21(1), 54-66. https://doi.org/10.1108/09649420610643411

Erdem, A. R. (1998). Süreç kuramlarının eğitim yönetimine katkıları. Pamukkale Üniversitesi Eğitim Fakültesi Dergisi, 4(4), 51-57.

Field, A. (2005). Discovering statistics using SPSS (2.Basim). Beverly Hills: Sage Publications.

Gattiker, U. E. ve Larwood, L. (1987). Career success, mobility and extrinsic career satisfaction studying corporate managers. Paper Presented at the Annual Meeting of the American Sociological Association, Chicago, Illinois.

Gerçek, M., Elmas-Atay, S. ve Dündar, G. (2015). Çalışanların iş-yaşam dengesi ile kariyer tatmininin, işten ayrılma niyetine etkisi. KAÜ IIBF Dergisi, 6(11), 67-86.

Gönen, S. ve Kocakaya, S. (2006). Fizik öğretmenlerinin hizmet-içi eğitimler üzerine görüşlerinin değerlendirilmesi. Pamukkale Üniversitesi Eğitim Fakültesi Dergisi, 19(19), 37-44.

Greenhaus, J. H., Parasuraman, S. ve Wormley, W. M. (1990). Effects of race on organizational experiences, job performance evaluations, and career outcomes. Academy of Management Journal, 33(1), 64-86. https://doi.org/10.5465/256352 
Gürkan, Ç. G. ve Koçoğlu, M. (2014). Yaratıcı örgüt ikliminin kariyer tatmini üzerine etkisinde duygusal bağlılı̆̆ın aracı değişken rolü: Türkiye'de bir vakıf ve bir devlet üniversitesinde karşılaştırmalı bir araştırma. Uluslararası Sosyal Araştırmalar Dergisi, 7(29), 588-602.

Güven-Yıldırım, E. ve Köklükaya, A. N. (2016). İlk ve ortaokul öğrencilerinin fen konularına yönelik ilgi düzeylerinin belirlenmesi. Amasya Üniversitesi Eğitim Fakültesi Dergisi, 5(1), 1-22. https://doi.org/10.17539/aej.20578

Hatipoğlu, A. ve Kavas, E. (2016). Veli yaklaşımlarının öğretmen performansına etkisi. İnsan ve Toplum Bilimleri Araştırmaları Dergisi, 5(4), 1012-1034.

Hendley, D., Stables, S. ve Stables, A. (1996). Pupils' subject preferences at key stage 3 in South Wales. $\quad$ Educational $\quad$ Studies, $\quad 2(22), \quad 177-186$. https://doi.org/10.1080/0305569960220204

Hirschi, A., Nagy, N., Baumeler, F., Johnston, C. S. ve Spurk, D. (2017). Assessing key predictors of career success: Development and validation of the career resources questionnaire. Journal of Career Assessment, 26(2), 338-358. https://doi.org/10.1177/1069072717695584

Hsu, M. K., Chen, H. G., Jiang, J. J. ve Klein, G. (2003). Career satisfaction for managerial and technical anchored IS personnel in later career stages. Database for Advances in Information Systems, 34(4), 64-72. https://doi.org/10.1145/957758.957766

Judge, A. T., Cable, M. D., Boudreau, W. J. ve Bretz, D. R. (1995). An empirical investigation of the predictors of executive career success. Personnel Psychology, 48, 485-519. https://doi.org/10.1111/j.1744-6570.1995.tb01767.x

Kendir, H. ve Özkoç, A. G. (2018). Otel işletmelerinde çalışanların kariyer tatmini ve kariyer bağl1lı̆̆ ilişkisinde öz yeterliliğin rolü. Journal of Tourism and Gastronomy Studies, 6(4), 78-112. https://doi.org/10.21325/jotags.2018.299

Kılınç, M. ve Uzun, K. (2020). Kariyer geliştirme uygulama ve araştırmaları için önemli bir kavram: Hizmet yönelimi. TAY Journal, 4(2), 92-121.

Kılınç, M. ve Uzun, K. (2021). Öğretmenler ve okul psikolojik danışmanları için pozitif psikoloji. G. Arslan ve M. Y1ldırım (Ed.), Okulda pozitif psikoloji: Kuramdan uygulamaya kitab1 içinde (ss. 333-368). Ankara: Pegem Akademi Yayıncıl1k.

Kline, P. (2014). An easy guide to factor analysis. New York: Routledge.

Knight, D. K., Crutsinger, C. ve Kim, H. (2006). The impact of retail work experience, career expectation, and job satisfaction on retail career intention. Clothing and Textiles Research Journal, 24(1), 1-14. https://doi.org/10.1177/0887302X0602400101

Koçoğlu, M. (2012). Çalışanların örgütlerine yönelik girişimcilik yönelimi algıları, örgüt desteği, kariyer tatminleri ve işten ayrllma niyetleri arasındaki ilişkinin incelenmesi: Otomotiv sektöründe bir araştırma (Yayımlanmamış doktora tezi). İstanbul Üniversitesi Sosyal Bilimler Enstitüsü, İstanbul.

Küçükusta, D. (2007). Konaklama işletmelerinde iş-yaşam dengesi sorunları ve çözüme yönelik yaklaşımlar. Dokuz Eylül Üniversitesi Sosyal Bilimler Enstitüsü Dergisi, 9(3), 243-268.

Liu, N. ve Liu, X. Y. (2008). A study on the assessment criteria of the career success of enterprise managers. Economic Survey, 5, 75-78. 
Lortie-Lussier, M. ve Rinfret, N. (2005). Determinants of objective and subjective success of men and women. International Review of Administrative Sciences, 71(4), 607-624. https://doi.org/10.1177/0020852305059601

Martins, L. L., Eddleston, K. A. ve Veiga, J. F. (2002). Moderators of the relationship between work-family conflict and career satisfaction. Academy of Management Journal, 45(2), 399-409. https://doi.org/10.5465/3069354

Mertler, C. A. ve Vannatta, R. A. (2016). Advanced and multivariate statistical methods: Practical application and interpretation (6.Basim). New York: Taylor \& Francis.

Nauta, A., Vianen, A. V., Heijden, B. V. D., Dam, K. V. ve Willemsen, M. (2009). Understanding the factors that promote employability orientation: The impact of employability culture, career satisfaction, and role breadth self-efficacy. Journal of Occupational and Organizational Psychology, 82, 233-251. https://doi.org/10.1348/096317908X320147

Ng, T. W. H., Eby, L. T., Sorensen, K. L. ve Feldman, D. C. (2005). Predictors of objective and subjective career success: A meta-analysis. Personnel Psychology, 58(2), 367-408. https://doi.org/10.1111/j.1744-6570.2005.00515.x

Özdemir, S. M. (2016). Öğretmen niteliğinin bir göstergesi olarak sürekli mesleki gelişim. Gazi Ë̆itim Bilimleri Dergisi, 2(3), 233-244.

Özen, Y. ve Gül, A. (2007). Sosyal ve eğitim bilimleri araştırmalarında evren-örneklem sorunu. Atatürk Üniversitesi Kazım Karabekir Eğitim Fakültesi Dergisi, 15, 394-422.

Özkişi, Z. G. (2012). Toplumsal cinsiyet bağlamında türkiye'de kadınların bestecilik eğitimine erişimi ve bestecilik kariyeri. Turkish Studies, 7(3), 2105-2114.

Peluchette, J. V. E. (1993). Subjective career success: The influence of individual difference, family, and organizational variables. Journal of Vocational Behavior, 43(2), 198-208. https://doi.org/10.1006/jvbe.1993.1042

Punnett, B. J., Duffy, J. A., Fox, S., Gregory, A., Lituchy, T., Miller, J., Inés-Monserrat, S., Olivas-Luján, M. R. ve Santos, N. M. B. F. (2007). Career success and satisfaction: A comparative study in nine countries. Women in Management Review, 22(5), 371-390. https://doi.org/10.1108/09649420710761446

Rasdi, R. M., Ismail, M. ve Garavan, T. N. (2011). Predicting Malaysian managers' objective and subjective career success. The International Journal of Human Resource Management, 22(17), 3528-3549. https://doi.org/10.1080/09585192.2011.560878

Rizzo, J. R., House, R. J. ve Lirtzman, S. I. (1970). Role conflict and ambiguity in complex organizations. Administrative Science Quarterly, 15(2), 150-163. https://doi.org/10.2307/2391486

Ronen, S. (1978). Job satisfaction and the neglected variable of job seniority. Human Relations, 31(4), 297-308. https://doi.org/10.1177/001872677803100401

Sağ, V. (2003). Toplumsal değişim ve eğitim üzerine. Cumhuriyet Üniversitesi Sosyal Bilimler Dergisi, 27(1), 11-25.

Sağdıç, M. ve Demirkaya, H. (2009). Üniversite öğrencilerinin kariyer gelişim planlarına ilişskin yaklaşımları. Erciyes Üniversitesi Sosyal Bilimler Enstitüsü Dergisi, 1(26), 233-246.

Seibert, S. E. ve Kraimer, M. L. (2001). The five-factor model of personality and career success. Journal of Vocational Behavior, 58(1), 1-21. https://doi.org/10.1006/jvbe.2000.1757

Sevimli, F. ve İşcan, Ö. F. (2005). Bireysel ve iş ortamına ait etkenler açısından iş doyumu. Ege Akademik Baklş, 5(12), 55-64.

Shanafelt, T. D., Balch, C. M., Bechamps, G. J., Russell, T., Dyrbye, L., Satele, D., Collicott, P., Novotny, P. J., Sloan, J. ve Freischlag, J. A. (2009). Burnout and career satisfaction 
among American surgeons. Annals of Surgery, 250(3), 463-471. https://doi.org/10.1097/SLA.0b013e3181ac4dfd

Shawer, S. F. ve Alkahtani, S. A. (2012). The relationship between program evaluation experiences and stakeholder career satisfaction. Creative Education, 3(8), 1336-1344. http://dx.doi.org/10.4236/ce.2012.38196

Tak, J. ve Lim, B. (2008). The differences in career-related variables between temporary and permanent employees in information technology companies in Korea. Journal of Career Development, 34(4), 423-437. https://doi.org/10.1177/0894845308316294

Tarı, H. (2011). İlköğretim okullarının 1. 2. 3. sinfflarında uygulanan güzel sanatlar dersinin ögretmen görüşlerine dayalı olarak değerlendirilmesi (Yayımlanmamış yüksek lisans tezi). Marmara Üniversitesi Eğitim Bilimleri Enstitüsü, İstanbul.

The Holmes Group (1996). Tomorrow's teachers: A report of the holmes group. The Holmes Group, East Lansing, MI.

Uzunbacak, H. H. (2004). Türk emniyet teşkilatının amir sinıfinın mesleki durgunluk (kariyer platosu) döneminin geciktirilmesine yönelik kariyer planlaması (Yayımlanmamış yüksek lisans tezi). Süleyman Demirel Üniversitesi Sosyal Bilimler Enstitüsü, Isparta.

Varol, S. ve Türkmen, M. (2017). Beden eğitimi öğretmeni adayı son sınıf öğrencilerinin beden eğitimi öğretim yeterlilik alg1 düzeylerinin belirlenmesi. Uluslararası Kültürel ve Sosyal Araştırmalar Dergisi, 3(2), 330-342.

Vatansever, Ç. (2008). Work and non-work life balance, and its relation to organizational commitment and career satisfaction (Yayımlanmamış doktora tezi). Marmara Üniversitesi Sosyal Bilimler Enstitüsü, İstanbul.

Wang, Y. F., Horng, J. S., Cheng, S. Y. ve Killman, L. (2011). Factors influencing food and beverage employees' career success: A contextual perspective. International Journal of Hospitality Management, 30, 997-1007. https://doi.org/10.1016/j.ijhm.2011.03.005

Yaman, S. ve Öner, F. (2006). İlköğretim öğrencilerinin fen bilgisi dersine bakış açılarını belirlemeye yönelik bir araştırma. Kastamonu Eğitim Dergisi, 14(1), 339-346.

Yap, M., Cukier, W., Holmes, M. R. ve Hannan, C. A. (2010). Career satisfaction: A look behind the races. Relations Industrielles / Industrial Relations, 65(4), 584-608. https://doi.org/10.7202/045587ar

Yüksel, İ. (2005). İş-aile çatışmasının kariyer tatmini, iş tatmini ve iş davranışları ile ilişkisi. Íktisadi ve İdari Bilimler Dergisi, 19(2), 301-314. 